\title{
AN EFFECTIVE PALYNOLOGICAL PREPARATION PROCEDURE USING HYDROGEN PEROXIDE
}

\author{
JAMES B. RIDING ${ }^{1}$ \\ JANE E. KYFFIN-HUGHES \\ BERNARD OWENS \\ British Geological Survey \\ Kingsley Dunham Centre \\ Keyworth \\ Nottingham NG12 5GG \\ United Kingdom \\ ${ }^{1}$ corresponding author, e-mail: jbri@bgs.ac.uk
}

\begin{abstract}
Most pre-Quaternary palynology samples are currently prepared by demineralisation of the sediment/sedimentary rock matrix using hydrochloric and hydrofluoric acids ( $\mathrm{HCl}$ and $\mathrm{HF}$ respectively). If a consistently effective alternative to this procedure can be developed, palynological processing will be made significantly less hazardous to both laboratory personnel, and to the wider environment. Furthermore, most non-acid processing methods are normally quicker and cheaper than matrix dissolution using acid. Some authors have previously used hydrogen peroxide $\left(\mathrm{H}_{2} \mathrm{O}_{2}\right)$ to extract palynomorphs by the physico-chemical disaggregation of the clay fraction. However, $\mathrm{H}_{2} \mathrm{O}_{2}$ is a powerful oxidizing agent and hence can potentially destroy sedimentary organic material, including palynomorphs. A new method using hot $\mathrm{H}_{2} \mathrm{O}_{2}$, where exposure of the sample material to the $\mathrm{H}_{2} \mathrm{O}_{2}$ is minimised, has been developed. Crushed sample material in a suitable vessel is placed on a hot plate for one minute, treated with $15-30 \% \mathrm{H}_{2} \mathrm{O}_{2}$ for 10 minutes, then the residue is diluted with cold distilled water. Disaggregated sample material tends to float, and is decanted into a large vessel containing distilled water to further dilute the $\mathrm{H}_{2} \mathrm{O}_{2}$. If any undisaggregated sample remains, the procedure is repeated several times if necessary. Relatively indurated sedimentary lithotypes normally require several treatments. The reason for this stepwise treatment is that the organic material is not exposed to $\mathrm{H}_{2} \mathrm{O}_{2}$ for sustained periods, thereby reducing the possibility of palynomorph damage/degradation due to oxidation. When the sample matrix has been fully disaggregated, the residue can be further processed as appropriate.

In this study, eight samples of Carboniferous, Jurassic, Paleogene, and Quaternary age were prepared quantitatively using the new $\mathrm{H}_{2} \mathrm{O}_{2}$ method. These were all prepared using $30 \% \mathrm{H}_{2} \mathrm{O}_{2}$. For comparison, they were also prepared quantitatively using $\mathrm{HCl} / \mathrm{HF}$ and/or sodium hexametaphosphate $\left[\left(\mathrm{NaPO}_{3}\right)_{6}\right]$. Quantitative preparations allow the concentration of palynomorphs extracted to be determined, and therefore the effectiveness of the techniques used can be compared objectively. The palynomorph residues derived from these three techniques varied markedly. $\mathrm{The}_{2} \mathrm{H}_{2} \mathrm{O}_{2}$ method does not consistently disaggregate all the sample material, particularly the older and more indurated lithotypes. Some evidence of oxidation effects was observed. Two samples of Mississippian mudstone from the U.S.A. were prepared using $\mathrm{H}_{2} \mathrm{O}_{2}$ and $\left(\mathrm{NaPO}_{3}\right)_{6}$. Both methods produced abundant miospores, however the $\mathrm{H}_{2} \mathrm{O}_{2}$ procedure yielded far higher palynomorph concentrations than the $\left(\mathrm{NaPO}_{3}\right)_{6}$
\end{abstract}


technique. Minor degradation of palynomorphs in the $\mathrm{H}_{2} \mathrm{O}_{2}$ preparation was noted. The $\mathrm{H}_{2} \mathrm{O}_{2}$ and $\mathrm{HCl} / \mathrm{HF}$ methods were compared directly on a palynomorph-rich sample of Upper Carboniferous mudstone from offshore Scotland. Both preparations produced abundant miospores. The $\mathrm{HCl} / \mathrm{HF}$ method had significantly higher recovery levels than the $\mathrm{H}_{2} \mathrm{O}_{2}$ procedure. It appears that the $\mathrm{H}_{2} \mathrm{O}_{2}$ method simultaneously macerates the matrix, and oxidizes any amorphous organic material (AOM) present. In this sample, the $\mathrm{HCl} / \mathrm{HF}$ residue was relatively rich in AOM. By contrast, the $\mathrm{H}_{2} \mathrm{O}_{2}$ preparation is virtually clear of this phytoclast type, which partially obscures palynomorphs. Two samples of the Middle Jurassic Grantham Formation of eastern England were processed using $\mathrm{H}_{2} \mathrm{O}_{2}$ and $\mathrm{HCl} / \mathrm{HF}$. The two methods produced abundant palynofloras of similar palynomorph concentrations. Two dinoflagellate cyst acmes within the Danian (Paleogene) part of the Lopez de Bertodano Formation of Seymour Island, Antarctica were also tested using $\mathrm{H}_{2} \mathrm{O}_{2},\left(\mathrm{NaPO}_{3}\right)_{6}$, and $\mathrm{HCl} / \mathrm{HF}$. The $\mathrm{H}_{2} \mathrm{O}_{2}$ preparation completely destroyed the dominant taxon, Palaeoperidinium pyrophorum, in one sample. By contrast, the $\left(\mathrm{NaPO}_{3}\right)_{6}$ and $\mathrm{HCl} / \mathrm{HF}$ preparations produced abundant, fully representative palynofloras. In the other sample, the acme of Spinidinium spp. is completely unaffected by the $\mathrm{H}_{2} \mathrm{O}_{2}$ preparation procedure. The final sample of this study is an unconsolidated clay of Late Pleistocene age from offshore Scotland. Both the $\mathrm{H}_{2} \mathrm{O}_{2}$ and $\mathrm{HCl} / \mathrm{HF}$ preparations proved similar in both taxonomic content and overall palynomorph yield.

The new method of preparation using hot $\mathrm{H}_{2} \mathrm{O}_{2}$ has proved to be extremely effective. In particular, it appears to be superior to the $\left(\mathrm{NaPO}_{3}\right)_{6}$ procedure for indurated lithotypes. However care should be taken because $\mathrm{H}_{2} \mathrm{O}_{2}$ can destroy certain dinoflagellate cysts and kerogen macerals which are especially susceptible to oxidation. Further development work, and more comparative testing of the $\mathrm{H}_{2} \mathrm{O}_{2}$, $\left(\mathrm{NaPO}_{3}\right)_{6}$, and $\mathrm{HCl} / \mathrm{HF}$ procedures, should be undertaken.

Key words: palynomorph preparation techniques; hydrogen peroxide; Carboniferous; Jurassic; Paleogene; Quaternary; Antarctica; U.K.; U.S.A.

\section{INTRODUCTION}

The traditional method of extracting palynomorphs from the sediment matrix uses hydrochloric acid ( $\mathrm{HCl}$ ) and hydrofluoric acid (HF) to remove the carbonate and silicate minerals respectively (Gray, 1965; Doher, 1980; Phipps and Playford, 1984; Traverse, 1988; Wood et al., 1996). Nitric acid $\left(\mathrm{HNO}_{3}\right)$ or other aggressive oxidizing agents are also normally used to remove any extraneous organic material. Due to the toxicity of these mineral acids, these procedures must be done in a fume hood. This procedure is potentially hazardous and polluting. Therefore effective non-acid preparation techniques would be significantly preferable. Other disadvantages of acid digestion are that the reagents are relatively expensive and reaction times can be long. Recently, a non-acid method using sodium hexametaphosphate $\left[\left(\mathrm{NaPO}_{3}\right)_{6}\right]$ was described (Riding and Kyffin-Hughes, 2004; 2006; Riding et al. 2006). In this method, the $\left(\mathrm{NaPO}_{3}\right)_{6}$ deflocculates the clay minerals, so they can be sieved away in order to concentrate the organic fraction. This non-acid technique is generally quicker and hence cheaper than the traditional acid-based procedure; it is unequivocally significantly safer and more environmentally friendly. It also has the significant advantage that it also extracts palynomorphs and other microfossils, notably silicofossils (Riding and Kyffin-Hughes, 2004, text-figs 6e, f)). The $\left(\mathrm{NaPO}_{3}\right)_{6}$ method 
has been tested on material of Ordovician, Carboniferous, Jurassic, Cretaceous, Paleogene, and Quaternary age. It appears to be less effective on carbonates and relatively highly indurated siliciclastic sample material (Riding and Kyffin-Hughes, $2004 ; 2006)$. The purpose of this contribution is to describe a new preparation method using hot hydrogen peroxide $\left(\mathrm{H}_{2} \mathrm{O}_{2}\right)$, and to report the results of testing this procedure on Carboniferous, Jurassic, Paleogene, and Quaternary sample material.

\section{THE PREVIOUSLY DESCRIBED USE OF HYDROGEN PEROXIDE IN PALYNOLOGICAL PROCESSING}

Hydrogen peroxide $\left(\mathrm{H}_{2} \mathrm{O}_{2}\right)$ physico-chemically disaggregates clay-rich sediments/sedimentary rocks, and therefore can extract calcareous microfossils, phosphatic microfossils, palynomorphs, and silicofossils. The effect of $\mathrm{H}_{2} \mathrm{O}_{2}$ on sediments and sedimentary rocks is simultaneously to break down the fabric, and to oxidize the organic material. Because $\mathrm{H}_{2} \mathrm{O}_{2}$ is a powerful oxidizing agent, great care must be taken to avoid damage to, and/or degradation of, the less robust palynomorphs (Hopkins and McCarthy, 2002). Leschik (1956) and Brown (1960) described using $\mathrm{H}_{2} \mathrm{O}_{2}$ to prepare brown coal; the $\mathrm{H}_{2} \mathrm{O}_{2}$ oxidizes the powdered coal prior to other chemical treatment. Smith and Butterworth (1967, p. 102) also described a procedure for preparing lignites by boiling in $\mathrm{H}_{2} \mathrm{O}_{2}$. These authors gently boiled $1 \mathrm{~g}$ of powdered coal in $50 \mathrm{ml}$ of $100 \% \mathrm{H}_{2} \mathrm{O}_{2}$ for at least six hours to oxidize the coal. Smith and Butterworth (1967) warned that if the coal is pyritic, this reaction can be violent. Funkhouser and Evitt (1959), Traverse (1988), and Eshet and Hoek (1996) mentioned the use of $\mathrm{H}_{2} \mathrm{O}_{2}$ as an oxidizing agent, used following $\mathrm{HCl} / \mathrm{HF}$ digestion. Furthermore, Jenkins (1967), Doher (1980), and Batten (1999) stated that $\mathrm{H}_{2} \mathrm{O}_{2}$ can be used to bleach darkened palynomorphs due to its oxidizing properties. Collinson (1980) briefly described the use of $\mathrm{H}_{2} \mathrm{O}_{2}$ to disaggregate a silty clay of Late Eocene age. The residue was sieved after $\mathrm{H}_{2} \mathrm{O}_{2}$ treatment, and palynomorphs were recovered. The extraneous mineral matrix was removed using HF, and the palynomorphs lightened with Schultze's solution. This disaggregation using $\mathrm{H}_{2} \mathrm{O}_{2}$ was previously used to extract sporangia from Paleogene clays from southern England (Collinson, 1978). Here the clays were soaked in dilute $\mathrm{H}_{2} \mathrm{O}_{2}$ solution for between 15 and 60 minutes. The $\mathrm{H}_{2} \mathrm{O}_{2}$ disaggregates the clay much more effectively than water or sodium carbonate $\left(\mathrm{Na}_{2} \mathrm{CO}_{3}\right)$ solution. Pearson and Scott (1999) mentioned that $10 \%$ $\mathrm{H}_{2} \mathrm{O}_{2}$ can be used to disaggregate some clay-rich lithotypes in order to release megaspores. Riding and Kyffin-Hughes $(2004 ; 2006)$ outlined the use of $\mathrm{H}_{2} \mathrm{O}_{2}$ treatment for 15-20 minutes in order to break down rock fragments that resisted disaggregation using $\left(\mathrm{NaPO}_{3}\right)_{6}$. Another significant paper on this topic is Williams et al. (2005) who described palynomorph preparation using $\mathrm{H}_{2} \mathrm{O}_{2}$, and demonstrated its utility in five case histories. These authors stated that trial and error are required to determine both the optimum concentration of $\mathrm{H}_{2} \mathrm{O}_{2}$, and the timing of the treatment. The nature of the palynomorphs and the lithology of the sample material determine both these parameters. Clay-rich material which has been buried to less than $3000 \mathrm{~m}$ needs a $6 \% \mathrm{H}_{2} \mathrm{O}_{2}$ solution. If the sample material is siltstone, and/or has been deeply buried, a $12 \%$ solution of $\mathrm{H}_{2} \mathrm{O}_{2}$ is preferable. The duration of the $\mathrm{H}_{2} \mathrm{O}_{2}$ treatment can vary from between 1 and 30 minutes, depending on the rate of disaggregation. Williams et al. (2005) used $3 \%$ to $12 \% \mathrm{H}_{2} \mathrm{O}_{2}$, and noted that certain dinoflagellate cyst taxa such as Palaeoperidinium pyrophorum can be destroyed. This phenomenon can be prevented by reducing the concentration of the reagent, and the duration of the 
treatment. When the sample is adequately disaggregated, the residue is passed through a nest of sieves with mesh sizes from $63 \mu \mathrm{m}$ to $1 \mathrm{~mm}$, and gravity-separated to concentrate the palynomorphs. The residue is cleaned of fine mineral particles and kerogen using sieves and detergent. Riding and Kyffin-Hughes (2006) prepared three Paleozoic samples using $\mathrm{H}_{2} \mathrm{O}_{2}$. The crushed sample was heated to $70^{\circ} \mathrm{C}$, covered in $\mathrm{H}_{2} \mathrm{O}_{2}$, and left for five minutes. It was then diluted with water at $60^{\circ} \mathrm{C}$ and left for 15 minutes, or until any reaction was complete. The residue was sieved at $10 \mu \mathrm{m}$ in order to remove the fine extraneous debris, then at $500 \mu \mathrm{m}$ to remove any $>500 \mu \mathrm{m}$ fragments. The process was repeated as many times as necessary until all the $>500$ $\mu \mathrm{m}$ fragments have disaggregated. The mineral fraction was separated using a suitable gravity method. This method proved ineffective on the Lower Ordovician (Tremadocian) Shineton Shale Formation and the Lower Carboniferous Lawmuir Formation. These were not fully disaggregated by this method. By contrast, a sample of the Lower Carboniferous Ballagan Formation produced a moderately abundant palynoflora using $\mathrm{H}_{2} \mathrm{O}_{2}$, but this was not as rich as the preparations made using $\mathrm{HCl} / \mathrm{HF}$ digestion and $\left(\mathrm{NaPO}_{3}\right)_{6}$ (Riding and Kyffin-Hughes, 2006, table 1, pl. 2, figs. $1,2)$. The reduced yield may be due to the oxidizing effects of $\mathrm{H}_{2} \mathrm{O}_{2}$.

Hydrogen peroxide is therefore an extremely important reagent in palynological preparation, especially when the use of mineral acids is precluded. However, because of the oxidizing effects of $\mathrm{H}_{2} \mathrm{O}_{2}$, more development work is needed to accurately assess its potential.

\section{THE NEW METHOD OF PALYNOMORPH PROCESSING USING HOT HYDROGEN PEROXIDE}

The method used in this study is described step-by-step in Appendix 1. Firstly the sample material is crushed, or broken up, to maximise the surface area in contact with the $\mathrm{H}_{2} \mathrm{O}_{2}$, and to minimise any mechanical damage to the palynomorphs. The fragmented sample is heated to ca. $100^{\circ} \mathrm{C}$ and treated with $15-30 \% \mathrm{H}_{2} \mathrm{O}_{2}$ for 10 minutes. The concentration of the $\mathrm{H}_{2} \mathrm{O}_{2}$ is dependent upon the induration level of the sample material. It was found that $\mathrm{H}_{2} \mathrm{O}_{2}$ is more effective on sample material which has been pre-heated. The residue is then diluted with water, causing the disaggregated material to float. This is decanted into a beaker containing water to dilute the $\mathrm{H}_{2} \mathrm{O}_{2}$. Frequently, some undisaggregated sample will remain. Therefore, the undisaggregated residue is reheated, and the 10 minute maceration in $\mathrm{H}_{2} \mathrm{O}_{2}$ is repeated as many times as necessary until all the sample is broken down. It may be possible and/or necessary to extend the treatment time, leaving the residue for longer than 10 minutes. When all of the sample material is entirely disaggregated, the aqueous residue can be further processed as appropriate.

The new method described here and the procedure of Riding and KyffinHughes (2006, p. 87) are somewhat similar. They are both based on the exposure to the heated sample material to $\mathrm{H}_{2} \mathrm{O}_{2}$ for relatively short periods of time (5-10 minutes) in order to disaggregate the outer surface. The treatment is done in a stepwise fashion so that the organic materials are not exposed to $\mathrm{H}_{2} \mathrm{O}_{2}$ for prolonged periods, hence the possibility of damage by oxidation is minimised. The new method is considered to be superior to that of Riding and Kyffin-Hughes (2006) because the sample has less contact time with the $\mathrm{H}_{2} \mathrm{O}_{2}$, and the residue does not need to be sieved after each exposure to $\mathrm{H}_{2} \mathrm{O}_{2}$. These factors meant that palynomorph losses via oxidation and during sieving are minimised. 


\section{HYDROGEN PEROXIDE - BACKGROUND AND HEALTH/SAFETY ASPECTS}

The systematic name of $\mathrm{H}_{2} \mathrm{O}_{2}$ is dihydrogen dioxide, but it is universally known as hydrogen peroxide. Pure $\mathrm{H}_{2} \mathrm{O}_{2}$ is a pale blue liquid, however it is colorless in dilute solution. It is a weak acid, and slightly more viscous than water. Because of its strong oxidizing properties, it has been used as a bleaching agent (e.g. for human hair), a disinfectant, and a propellant. Hydrogen peroxide is used extensively to bleach paper and pulp, and in the chemical industry.

The principal hazards of $\mathrm{H}_{2} \mathrm{O}_{2}$ are that it is a strong oxidant and it is corrosive, especially at concentrations greater than $50 \%$. However, typical concentrations are between 3 and $35 \%$; solutions greater than $60 \%$ present markedly increased risks. It is non-flammable, however it can form potentially explosive compounds when combined with several other chemicals and materials. The latter include inorganic and organic compounds, and metallic elements. Furthermore, $\mathrm{H}_{2} \mathrm{O}_{2}$ readily dissociates, especially when heated, to form water and oxygen. Naturally, any build-up of oxygen represents an increased fire hazard. Hence it should not be stored, or used, close to any potential fuels. The concentrations of $\mathrm{H}_{2} \mathrm{O}_{2}$ used in microfossil extraction sensu lato (i.e. $<30 \%$ ) are such that these hazards are minimal, given safe laboratory practice. For example, potentially explosive $\mathrm{H}_{2} \mathrm{O}_{2}$ vapor is only given off using ca. $>70 \% \mathrm{H}_{2} \mathrm{O}_{2}$ at $>70^{\circ} \mathrm{C}$. It also should be stored in cool conditions in robust containers made from a neutral (i.e. nonreactive or noncatalytic) material. Up to date safety data for $30 \% \mathrm{H}_{2} \mathrm{O}_{2}$ are given as a Manufacturer's Safety Data Sheet at: http://ptcl.chem.ox.ac.uk/MSDS/HY/hydrogen_peroxide_30pc.html.

In terms of safe palynology laboratory operations, this means storing the $\mathrm{H}_{2} \mathrm{O}_{2}$ in a suitable cool, dark place which is well separated from any potential fuels. It should be handled with care, as all chemical reagents are in a well run laboratory. Hydrogen peroxide is far less corrosive than hydrochloric and hydrofluoric acids, but should be used with similar safeguards and precautions. This is a new technique, and every laboratory undertaking this procedure should undertake a thorough risk assessment. The principal risk associated with the method is the fact that when heated, $\mathrm{H}_{2} \mathrm{O}_{2}$ gives off oxygen. Therefore, $\mathrm{H}_{2} \mathrm{O}_{2}$ should be used in an efficient fume cupboard while wearing adequate personal protective equipment, most importantly safety glasses and acid-resistant gloves. The most important factor is that the fume cupboard effectively removes the oxygen which is given off so that there is no build-up in the fume cupboard. The use of $\mathrm{H}_{2} \mathrm{O}_{2}$ in the technique described herein is entirely safe, provided there are no potential fuel materials in the fume cupboard, and/or substances whose vapor could mix with the oxygen given off during the maceration. Due to the wide range of materials which are flammable in the presence of increased oxygen levels, $\mathrm{H}_{2} \mathrm{O}_{2}$ macerations should be done in a dedicated, otherwise empty, fume cupboard with the sash down. Obviously, a fuel vapor/oxygen mixture is potentially explosive and flammable. This means, for example, that organic liquids should not be in, or near to, the fume cupboard during maceration with $\mathrm{H}_{2} \mathrm{O}_{2}$.

\section{MATERIALS AND METHODS}


In this study, eight samples of Carboniferous, Jurassic, Paleogene, and Quaternary age were prepared using hot $30 \% \mathrm{H}_{2} \mathrm{O}_{2}$. For comparative purposes, the samples were also prepared using the traditional $\mathrm{HCl} / \mathrm{HF}$ acid digestion technique and/or the technique using $\left(\mathrm{NaPO}_{3}\right)_{6}$ of Riding and Kyffin-Hughes (2004). The samples are listed in Appendix 2, and selected low-magnification photomicrographs of the residues are presented in Plates 1-5. All rock samples, organic residues, microscope slides, primary data, and illustrated material are housed in the collections of the British Geological Survey (BGS), Keyworth, Nottingham, U.K. All the palynomorph taxa at and below species level which are mentioned are listed in Appendix 3, with their respective author citations. The new preparation procedure using $\mathrm{H}_{2} \mathrm{O}_{2}$ is outlined in Appendix 1. The eight samples were prepared quantitatively using the method described by Harland (1989) and Gelsthorpe (2002). This allows the palynomorphs extracted per gram of sample to be determined. This quantitative method allows the effectiveness of both the techniques used to be objectively compared. The quantitative results are given in Table 1 . The palynomorph residues derived from the $\mathrm{H}_{2} \mathrm{O}_{2},\left(\mathrm{NaPO}_{3}\right)_{6}$, and $\mathrm{HCl} / \mathrm{HF}$ preparations vary significantly. For example, the $\mathrm{H}_{2} \mathrm{O}_{2}$ treatment does not consistently disaggregate all the sample material, especially in the case of some of the older and more indurated sedimentary rocks (Table 1).

\section{CASE STUDIES}

\section{The Portsmouth Member, Cuyahoga Formation (Lower Carboniferous, Mississippian, Kinderhookian/Osagean) of the Springville Hill road cutting, South Portsmouth, Kentucky, U.S.A (samples 1 and 2; $\mathrm{H}_{2} \mathrm{O}_{2}$ and $\left(\mathrm{NaPO}_{3}\right)_{6}$ preparation methods, both quantitative)}

Two samples of the Portsmouth Shale Member of the Cuyahoga Formation were collected from Springville Hill road cutting, directly across the Ohio River from Portsmouth, Ohio. The Two Mile Hill section, north of Portsmouth, is traditionally regarded as the type section of the Portsmouth Shale Member, but no formal type section was designated by Hyde (1915). The Springville Hill road cutting is considered to be an important reference section. This succession is known to be rich in palynomorphs.

The samples are both mudstones and were processed using $\mathrm{H}_{2} \mathrm{O}_{2}$ and $\left(\mathrm{NaPO}_{3}\right)_{6}$. There was insufficient material to prepare the samples using $\mathrm{HCl} / \mathrm{HF}$. Samples 1 and 2 both produced extremely abundant miospores which are light to dark brown in color (Plate 1). Representatives of the spore genera Spelaeotriletes and Vallatisporites are especially common, and both samples also contain a significant number of undescribed taxa. Acritarchs, which are significantly lighter in color compared to the miospores, are also present in relatively low proportions. Dark wood fragments also occur in moderate numbers. Precise interpretation of the age of the samples is difficult in the absence of a published biozonation for the Mississippian in North America. Coleman and Clayton (1987) have investigated an extended Mississippian section exposed along Interstate Highway 64 between Lexington and Morehead, Kentucky which provides the only reliable local database. The Interstate Highway 64 study provides the best available correlation between palynomorph asemblages and the standard North American chronostratigraphic scheme, in addition 
to suggested correlations with the western European palynozonation scheme for the Mississippian (Clayton et al., 1977).

Although there are no consistent preservational differences between components in either of the two assemblages, it is clear that they contain both in-situ and reworked components. The youngest (i.e. in-situ) association is dominated by Spelaeotriletes balteatus and Spelaeotriletes pretiosus, together with Acanthotriletes acritarchus, Acanthotriletes macrogaleatus, Acanthotriletes persibus,

Baculatisporites fusticulus, Camptotriletes prionotus, Colatisporites decorus, Convolutispora major, Neoraistrickia logani, Raistrickia condylosa, Raistrickia strumosa, Vallatisporites ciliaris, and Verrucosisporites irregularis. This association compares closely with those reported by Coleman and Clayton (1987) from the interval of the Borden Formation between the uppermost part of the Henley and Cowbell members. An early Osagean age was suggested for this succession, and a correlation to the Spelaeotriletes pretiosus-Raistrickia clavata (PC) miospore Biozone of Clayton et al. (1977) in western Europe was proposed. However, a latest Kinderhookian age for the section cannot be precluded because a palynologically barren interval in the lower part of the Henley Member, which may contain the Kinderhookian-Osagean boundary, was encountered in the Interstate 64 section.

The older, reworked, association in both samples represents a small percentage of the total palynofloras, but was identified by the presence of Apiculiretusispora fructicosa, Emphanisporites annulatus, Hymenozonotriletes explanatus, Retispora lepidophyta, Retispora lepidophyta var. minor, and Vallatisporites pusillites. The distinctive association of Retispora lepidophyta and Vallatisporites pusillites is a characteristic component of latest Devonian and earliest Mississippian assemblages in Europe and North America, and has been previously reported from the Bedford Shale in Ohio and Kentucky (Winslow, 1962; Molyneux et al., 1984, Coleman and Clayton, 1987; Clayton et al. 1998). This association, which is accompanied by several Late Devonian-Early Mississippian acritarchs including Gorgonisphaeridium, Leiosphaeridia, Multiplicisphaeridium, Umbellisphaeridium, and Veryhachium, is considered to be present in the Portsmouth Shale due to reworking of material from an older Bedford Shale source. Both assemblages contain a further group of long ranging taxa including Auroraspora macra, Retusotriletes incohatus, Spinozonotriletes uncatus, Verrucosisporites nitidus, Vallatisporites vallatus, and Vallatisporites verrucosus, which have been previously reported throughout the Lower Mississippian (Coleman and Clayton, 1987; Clayton et al., 1998).

There are no differences in the diversity and relative proportions in the subsamples prepared using the $\mathrm{H}_{2} \mathrm{O}_{2}$ and $\left(\mathrm{NaPO}_{3}\right)_{6}$ methods. It is clear that both provide fully representative associations. The majority of the spores are wellpreserved, however, some specimens appear to be somewhat degraded. These pale and degraded spores appear to be more prevalent in the material prepared using $\mathrm{H}_{2} \mathrm{O}_{2}$ (Plate 1, fig. 1). Furthermore, the rare acritarchs are most common in the $\left(\mathrm{NaPO}_{3}\right)_{6}$ preparations. The presence of significant numbers of apparently degraded spores, and the virtual lack of acritarchs, in the $\mathrm{H}_{2} \mathrm{O}_{2}$ preparations may be a result of the effects of oxidation by $\mathrm{H}_{2} \mathrm{O}_{2}$. In samples 1 and 2 , the palynomorph concentrations are 4,080 and 2,830 grains per gram respectively with the $\mathrm{H}_{2} \mathrm{O}_{2}$ method (Table 1). The $\left(\mathrm{NaPO}_{3}\right)_{6}$ method produced significantly sparser associations, 835 and 390 grains per gram respectively (Table 1). For sample 1 prepared with $\mathrm{H}_{2} \mathrm{O}_{2}$, this figure was calculated as follows. A total of 408 palynomorphs were counted using $0.05 \mathrm{ml}$ from a total of $5 \mathrm{ml}$ of homogenised aqueous organic residue prepared from $10 \mathrm{~g}$ of sample. This gives a figure of 4,080 palynomorphs per gram. All the other quantitative calculations in this 
study were made using this method. It is clear from the nature of the palynofloras produced from samples 1 and 2 using the two non-acid methods that both techniques can effectively extract palynomorphs from moderately well lithified claystones that are inherently palynologically rich. In this case, is possible that the $\mathrm{H}_{2} \mathrm{O}_{2}$ method causes some palynomorph damage and degradation. However, this method produced a significantly higher palynomorph concentration than the $\left(\mathrm{NaPO}_{3}\right)_{6}$ procedure (Table 1). This is thought to be because the $\mathrm{H}_{2} \mathrm{O}_{2}$ method is more effective at breaking down the lithified rock matrix than $\left(\mathrm{NaPO}_{3}\right)_{6}$.

\section{The Upper Carboniferous (Westphalian) of British Geological Survey offshore borehole at site 74/13, east of Fife Ness, Forth Approaches, offshore Scotland, U.K. (sample 3; $\mathrm{H}_{2} \mathrm{O}_{2}$ and $\mathrm{HCl} / \mathrm{HF}$ preparation methods, both quantitative)}

A single sample of mudstone, number 3, was collected at $18.07 \mathrm{~m}$ from this shallow $(77.00 \mathrm{~m})$, cored offshore borehole. It was drilled in 1974 as part of a major BGS offshore geological mapping project, and is mentioned in Institute of Geological Sciences (1975, p. 24) and Owens and Marshall (1978, p. 19). The site lies immediately east of Fife Ness, southeast Scotland, and was illustrated in Owens and Marshall (1978, text-fig. 3). The borehole penetrated till and shelly sand of Quaternary age to $17.00 \mathrm{~m}$, prior to coring $60.00 \mathrm{~m}$ of interbedded coal seams, mudstones, sandstones, and siltstones of Late Carboniferous (Westphalian B) age.

Sample 3, which is known to be palynologically rich, was prepared using $\mathrm{H}_{2} \mathrm{O}_{2}$ and $\mathrm{HCl} / \mathrm{HF}$. Both preparations yielded exceptionally abundant and wellpreserved miospores which are mid to dark brown in color (Plate 2). Spores are markedly more abundant than pollen, and microplankton is entirely absent. Relatively low proportions of wood fragments are also present. The sample yielded a well preserved, typical middle Pennsylvanian-Duckmantian (late Bashkirian-early Moscovian or Atokan) miospore assemblage dominated by approximately $80 \%$ Lycospora pusilla with common Crassispora and Florinites. The presence of the index species Endosporites globiformis and Florinites junior indicates assignment to the Microreticulatisporites nobilis-Florinites junior (NJ) Biozone of Clayton et al. (1977). This is supported by the presence of characteristic components of the NJ Biozone including Cirratriradites saturni, Cristatisporites indignabundus, Grumosisporites varioreticulatus, Raistrickia fulva, Raistrickia saetosa, Raistrickia superba, Reinschospora triangularis, Simozonotriletes intortus, Triquitrites bransonii, Triquitrites sinani, Vestispora cancellata, and Vestispora costata.

There are no differences in either diversity or relative proportions between the $\mathrm{H}_{2} \mathrm{O}_{2}$ and $\mathrm{HCl} / \mathrm{HF}$ preparations. Furthermore, absolutely no damage or degradation of the palynomorphs due to oxidation effects were observed in the $\mathrm{H}_{2} \mathrm{O}_{2}$ preparation (Plate 2). The $\mathrm{HCl} / \mathrm{HF}$ preparation was not oxidized, and it contains significant levels of amorphous organic material (AOM) (Plate 2, fig. 2). This extraneous material could be readily eliminated by a brief wash with nitric acid $\left(\mathrm{HNO}_{3}\right)$. The reason for the $\mathrm{H}_{2} \mathrm{O}_{2}$ preparation being clear of AOM in this study (Plate 2, fig. 1) is that this was oxidized during the maceration with $\mathrm{H}_{2} \mathrm{O}_{2}$. Consistency in not separately oxidizing the residues was maintained throughout this study in order to be able to make objective comparisons of the $\mathrm{H}_{2} \mathrm{O}_{2}$ and the $\mathrm{HCl} / \mathrm{HF}$ methods. The simultaneous breaking down of the matrix and the oxidation of the $\mathrm{AOM}$ by $\mathrm{H}_{2} \mathrm{O}_{2}$ is an extremely useful property, except in kerogen/palynofacies studies. However, if the palynomorphs are potentially susceptible to oxidation, they may be damaged. 
The quantitative analyses of the two preparation methods gave significantly different results. The $\mathrm{H}_{2} \mathrm{O}_{2}$ and $\mathrm{HCl} / \mathrm{HF}$ preparations yielded 2,994 and 54,600 grains per gram respectively (Table 1). The $\mathrm{H}_{2} \mathrm{O}_{2}$ method did not break the entire rock sample down, explaining the marked disparity in yield. Non-acid techniques are known to be somewhat less effective in the breakdown of relatively hard and indurated sedimentary rocks (Riding and Kyffin-Hughes, 2006). In the non-acid methods, ions of the reagent are adsorbed, and this disaggregates the clays due to the high ionic charges. The disaggregation effect is significantly less effective on hard claystones, than it is on soft, unconsolidated clays. This disparity in the different effectiveness of $\mathrm{H}_{2} \mathrm{O}_{2}$ and $\mathrm{HCl} / \mathrm{HF}$ in breaking down the bulk of the sediment matrix is not a serious problem in highly palynomorph-rich material such as sample 3 . In rich material such as sample 3 , the $\mathrm{H}_{2} \mathrm{O}_{2}$ method will demonstrably extract sufficient material for study which is apparently representative of the sample (Plate 2, fig. 1). Should the sample material be less rich in palynomorphs, the sample could be repeatedly macerated in stronger $\mathrm{H}_{2} \mathrm{O}_{2}$ in order to extract workable palynofloras. It is possible that the $\mathrm{H}_{2} \mathrm{O}_{2}$ method can be adapted to be more effective in the breakdown of the rock matrix provided a method can be found of softening it prior to $\mathrm{H}_{2} \mathrm{O}_{2}$ treatment.

\section{The Grantham Formation (Aalenian, Middle Jurassic) of the BGS Copper Hill Borehole, near Ancaster, Lincolnshire, England (samples 4 and 5; $\mathrm{H}_{2} \mathrm{O}_{2}$ and $\mathrm{HCl} / \mathrm{HF}$ preparation methods, both quantitative)}

Two samples, numbers 4 and 5, were prepared from this stratigraphic borehole drilled during early 1991 at Copper Hill Quarry, near Ancaster, Lincolnshire, central England (NGR SK 9787 4265). This borehole was drilled in order to prove the Middle and Lower Lias succession of the Grantham area. It is $202.11 \mathrm{~m}$ deep, and cored a succession from the Scunthorpe Mudstone Formation (Lower Sinemurian) to the Lower Lincolnshire Limestone Formation (Aalenian) (Berridge et al., 1999, textfigs. 19-21). The Copper Hill Borehole and the BGS Walks Farm Borehole (Berridge et al., 1999, text-figs. 22, 24) provide an important Jurassic reference section approximately $320 \mathrm{~m}$ thick for the East Midlands Shelf. Samples 4 and 5 (5.10-5.20 and 7.00 m respectively) are from a mudstone unit within the Grantham Formation, which is of Aalenian age (Murchisonae Chronozone) (Berridge et al., 1999, table 7). They are known to yield rich and well-preserved associations of pollen and spores with associated wood and plant fragments (Riding, 1992).

The $\mathrm{H}_{2} \mathrm{O}_{2}$ and the $\mathrm{HCl} / \mathrm{HF}$ preparations both yielded identical abundant palynomorphs which are mid brown in color (Table 1, Plate 3). No diversity or abundance differences were observed. Gymnospermous pollen and pteridophytic spores are present in subequal proportions. Both samples are also rich in wood and other plant material; AOM is absent. The pollen and spores observed from samples 4 and 5 include bisaccate pollen, Baculatisporites comaumensis, Callialasporites dampieri, Callialasporites microvelatus, Callialasporites turbatus, Cibotiumspora juriensis, Classopollis classoides, Concavissimisporites verrucosus, Coronatispora valdensis, Cyathidites spp., Duplexisporites problematicus, Gleicheniidites senomicus, Ischysporites variegatus, Leptolepidites spp., Perinopollenites elatoides, Retitriletes austroclavatidites, Todisporites spp., Uvaesporites argentiformis, and Vitreisporites pallidus. This pollen/spore association is typical of the paralic Aalenian-Bathonian facies in the Middle Jurassic of northwest Europe (Srivastava, 
1987; Riding et al., 1991). The freshwater/brackish alga Botryococcus braunii is also present.

The taxa present appeared to be entirely unaffected by either of the preparation methods. Specifically, the palynomorphs in the $\mathrm{H}_{2} \mathrm{O}_{2}$ preparation show absolutely no evidence of damage or degradation effects (Plate 3, fig. 1). However, it is possible that the $\mathrm{H}_{2} \mathrm{O}_{2}$ oxidized some of the light plant tissue (Plate 3). Quantitative analyses of the two preparation methods gave remarkably similar results. Sample 4 yielded 6,560 and 7,370 grains per gram with the $\mathrm{H}_{2} \mathrm{O}_{2}$ and $\mathrm{HCl} / \mathrm{HF}$ preparations respectively (Table 1). Using the $\mathrm{H}_{2} \mathrm{O}_{2}$ and $\mathrm{HCl} / \mathrm{HF}$ procedures, sample 5 produced 8,170 and 8,250 grains per gram respectively (Table 1 ). Both methods readily broke the entire rock sample down, and this explains the similar palynomorph concentrations and spectra. The fact that $\mathrm{H}_{2} \mathrm{O}_{2}$ is equally effective as $\mathrm{HCl} / \mathrm{HF}$ confirms that the non-acid techniques are viable alternatives to mineral acids for lightly or moderately indurated clay-rich sample material (Riding and Kyffin-Hughes, 2004; 2006).

The uppermost López de Bertodano Formation (Danian, Lower Paleogene) of Seymour Island, northern Antarctic Peninsula (sample 6: $\mathrm{H}_{2} \mathrm{O}_{2},\left(\mathrm{NaPO}_{3}\right)_{6}$, and $\mathrm{HCl} / \mathrm{HF}$ preparation methods, all quantitative; sample $7 ; \mathrm{H}_{2} \mathrm{O}_{2}$, and $\mathrm{HCl} / \mathrm{HF}$ preparation methods, both quantitative)

Samples 6 and 7, from the uppermost López de Bertodano Formation from south-central Seymour Island, offshore northeast Antarctic Peninsula were selected for this study. The samples were taken from measured section D5 229, which was part of a major sampling progam of the entire López de Bertodano Formation of southern Seymour Island (Thorn et al., 2007). The location of the measured section D5 229, and a summary sedimentological log, were illustrated by Thorn et al. (2007, text-figs. 3, 4). The López de Bertodano Formation of the Marambio Group is of Maastrichtian to Danian age, and outcrops in the upper part of a back-arc basin fill which represents an extensive regressive megasequence (Pirrie et al., 1992; Crame et al., 2004). The two samples are from immediately above the Maastrichtian-Danian $(\mathrm{K} / \mathrm{T})$ boundary, close to the boundary with the overlying Sobral Formation. Samples 6 and 7 represent acmes of the dinoflagellate cysts Palaeoperidinium pyrophorum and Spinidinium sp. respectively. These distinctive, stratigraphically restricted 'flood' occurrences were interpreted as representing restricted inshore-estuarine paleoenvironments, or settings where a single taxon invaded a vacant ecological niche (Askin, 1988a,b). Given that the paleoenvironment probably was significantly disrupted by the effects of the $\mathrm{K} / \mathrm{T}$ impact event, it seems most likely that these acmes represent opportunistic forms which recolonised devastated habitats. The reason for choosing these closely related two dinoflagellate cyst acmes was to test the contention of Williams et al. (2005) that $\mathrm{H}_{2} \mathrm{O}_{2}$ destroys certain peridiniacean dinoflagellate cyst taxa such as Palaeoperidinium pyrophorum. Hence, assuming that Spinidinium is not adversely affected by $\mathrm{H}_{2} \mathrm{O}_{2}$, sample 7 acts as a control. The López de Bertodano Formation is known to be palynologically rich (Riding et al., 1992). Sample 6 was prepared using the $\mathrm{H}_{2} \mathrm{O}_{2}$, $\left(\mathrm{NaPO}_{3}\right)_{6}$, and $\mathrm{HCl} / \mathrm{HF}$ methods so that the two non-acid procedures could be directly compared because of the potential damage to Palaeoperidinium pyrophorum using $\mathrm{H}_{2} \mathrm{O}_{2}$. By contrast, sample 7 was prepared using the $\mathrm{H}_{2} \mathrm{O}_{2}$ and $\mathrm{HCl} / \mathrm{HF}$ procedures.

Sample 6. This sample yielded an extremely abundant palynoflora. The assemblage is overwhelmingly dominated by the dinoflagellate cyst Palaeoperidinium pyrophorum 
(Plate 4). Other dinoflagellate cysts are present in relatively low proportions and include Cassidium fragile, Eisenackia circumtabulata, Hystrichosphaeridium salpingophorum, Senegalinium obscurum, and Trithyrodinium evittii. This assemblage is clearly within the Early Paleogene (Danian) dinoflagellate cyst zone 5 of Askin (1988a). The freshwater/brackish alga Botryococcus braunii was also observed in relatively small numbers. Palambages is also present, together with pollen and spores including Azolla sp., bisaccate pollen, Cyathidites spp., Laevigatosporites spp., Microcachryidites antarcticus, Nothofagidites spp., Peninsulapollis truswelliae, Proteacidites spp., Retitriletes austroclavatidites, and Stereisporites spp. The pollen-spore association is similar to those documented by Askin $(1990 \mathrm{a}, \mathrm{b})$ from the López de Bertodano Formation of Seymour Island.

The $\mathrm{H}_{2} \mathrm{O}_{2},\left(\mathrm{NaPO}_{3}\right)_{6}$, and $\mathrm{HCl} / \mathrm{HF}$ preparations proved significantly different, in terms of palynomorph productivity and content. The three methods produced 3,575, 11,700 , and 22,700 palynomorphs per gram of sediment respectively (Table 1). Despite the concentration differences between them, the $\left(\mathrm{NaPO}_{3}\right)_{6}$ and $\mathrm{HCl} / \mathrm{HF}$ preparations are identical in terms of general appearance, preservational state, and abundance/diversity (Plate 4). It is, however clear that the $\mathrm{HCl} / \mathrm{HF}$ method is significantly more effective at extracting palynomorphs from this sediment in terms of grains per gram. The acid method produced approximately double the numbers of palynomorphs than the $\left(\mathrm{NaPO}_{3}\right)_{6}$ method (Table 1). Furthermore, the $\mathrm{H}_{2} \mathrm{O}_{2}$ preparation proved richer in resistant mineral grains than the other preparations. The most important finding here is that Palaeoperidinium pyrophorum is entirely absent from the $\mathrm{H}_{2} \mathrm{O}_{2}$ residue. The residues produced with the $\mathrm{HCl} / \mathrm{HF}$ and $\left(\mathrm{NaPO}_{3}\right)_{6}$ methods produced superabundant Palaeoperidinium pyrophorum, and this taxon dominates the assemblage (Plate 4). However, the slides from the $30 \% \mathrm{H}_{2} \mathrm{O}_{2}$ procedure proved entirely devoid of this distinctive dinoflagellate cyst, hence the oxidizing effects of $\mathrm{H}_{2} \mathrm{O}_{2}$ have destroyed all the specimens of Palaeoperidinium pyrophorum. This confirms the findings of Williams et al. (2005, p. 220), who found that Palaeoperidinium pyrophorum is destroyed in certain samples by $3-12 \% \mathrm{H}_{2} \mathrm{O}_{2}$. It is clear that a reduced concentration of $\mathrm{H}_{2} \mathrm{O}_{2}$ will not destroy at least some of the Palaeoperidinium pyrophorum specimens (see Williams et al., 2005, text-figs. 6, 7), but these authors did not state this figure, or the range of concentrations. In this study, the standard $\mathrm{H}_{2} \mathrm{O}_{2}$ concentration (i.e. $30 \%$ ) was used on sample 6 in order to directly compare with the other samples herein. Recent peridiniacean dinoflagellate cysts are known to be more prone to damage by oxidation in comparison to gonyaulacalean forms (Dale, 1976; Head, 1996). This situation, however, is not always the case. By contrast, Dodsworth (1995) found that the prolonged oxidation of Cretaceous residues with Schulze's solution and alkali selectively and progressively destroyed gonyaulacacean dinoflagellate cysts. The peridiniacean dinoflagellate cyst taxa remained unaffected. Because of the findings of Dale (1976), most workers on Quaternary dinoflagellate cysts do not oxidize at all during preparation (e.g. Harland, 1989). In particular, it is well known that dinoflagellate cysts belonging to the Subfamily Congruentidioideae are highly susceptible to oxidation during processing (Head, 1996). For example, the genus Brigantedinium is extremely prone to destruction by even low levels of oxidation with $\mathrm{H}_{2} \mathrm{O}_{2}$ (Hopkins and McCarthy, 2002). It therefore appears that certain taxa throughout the Suborder Peridiniineae are prone to destruction by oxidation. However, although $\mathrm{H}_{2} \mathrm{O}_{2}$ destroys Palaeoperidinium pyrophorum, there is clearly significant variation because the peridinialean taxa Senegalinium obscurum and Trithyrodinium evittii are both present in the $\mathrm{H}_{2} \mathrm{O}_{2}$ preparation. These taxa belong to the Subfamily Deflandreoideae 
(Fensome et al., 1993). It is possible that Palaeoperidinium pyrophorum is especially susceptible to destruction via oxidation is because it is highly unusual in forming exterior to the dinoflagellate theca (Evitt et al., 1998). The dinosporin chemistry hence may be different to conventional dinoflagellate cysts, which form inside the theca. The destruction of such an important dinoflagellate cyst taxon as Palaeoperidinium pyrophorum due to the action of $\mathrm{H}_{2} \mathrm{O}_{2}$ is a major disadvantage to this method. The range top of this species is a reliable marker for the mid Thanetian (Powell, 1992). The strength of the $\mathrm{H}_{2} \mathrm{O}_{2}$, and the duration of the exposure should be tested using similar material so that a tolerance level can be formulated.

The remainder of the palynoflora appears to be entirely unaffected, although some pale relatively poorly-preserved palynomorphs were noted in the the $\mathrm{H}_{2} \mathrm{O}_{2}$ preparation, indicating that the $\mathrm{H}_{2} \mathrm{O}_{2}$ did cause some limited degradation to other palynomorphs than Palaeoperidinium pyrophorum. Obviously, the lack of Palaeoperidinium pyrophorum in the $\mathrm{H}_{2} \mathrm{O}_{2}$ preparation enhances the relative proportions of the rarer forms. This is similar to the effect noted by Hughes et al. (1964) when these authors prepared some coals using strong oxidants. Hughes et al. (1964) found that the spore Crassispora kosankei was destroyed by Schultze's solution. By contrast, Laevigatosporites spp. were found to be highly resistant and hence were overrepresented in overoxidized material.

Sample 7. This sample from Seymour Island also proved extremely rich palynologically. Like sample 6 , a dinoflagellate cyst acme is present. The dinoflagellate cyst assemblage is a virtually monospecific association of a representative of Spinidinium. This form was termed Spinidinium sp. 1 by Askin (1988a,b), and it overwhelmingly dominates the palynoflora (Plate 5). Other dinoflagellate cysts are extremely rare, and largely comprise Hystrichosphaeridium salpingophorum. Botryococcus braunii is also present. Pollen and spores are also relatively prominent. These are similar to those in sample 6 , and are dominated by spores, especially Cyathidites spp. The palynoflora is also within the Early Paleogene (Danian) dinoflagellate cyst zone 5 of Askin (1988a).

The $\mathrm{H}_{2} \mathrm{O}_{2}$ and $\mathrm{HCl} / \mathrm{HF}$ preparations were both highly palynologically productive. They produced 51,810 and 130,850 specimens per gram respectively (Table 1, Plate 5). Both methods fully broke down the sediment, and it is not known why there is such a large disparity in the palynomorph concentrations. It is possible that some palynomorphs were lost in the $\mathrm{H}_{2} \mathrm{O}_{2}$ preparation due to non-selective oxidation, and during sieving and other procedures. Also, there are slightly more mineral grains in the $\mathrm{H}_{2} \mathrm{O}_{2}$ preparation than the $\mathrm{HCl} / \mathrm{HF}$ residue; these may have displaced palynomorphs. Nevertheless, both these methods of preparation have produced highly abundant palynomorph associations, which are identical in terms of species content and relative proportions. It is clear that the $\mathrm{H}_{2} \mathrm{O}_{2}$ has not selectively degraded or destroyed specimens of Spinidinium (Plate 5).

\section{Quaternary (Late Pleistocene) clays of the BGS offshore borehole 99/3, Faroes- Shetland area, offshore northern Scotland (Judd Sheet) (sample 8; $\mathrm{H}_{2} \mathrm{O}_{2}$ and $\mathrm{HCl} / \mathrm{HF}$ preparation methods, both quantitative)}

Sample 8 is from $34.22 \mathrm{~m}$ in a BGS offshore borehole, number 99/3, which drilled a succession of Quaternary clays offshore northern Scotland. The borehole is located at $60^{\circ} 24.8133^{\prime} \mathrm{N} ; 04^{\circ} 39.0639^{\prime} \mathrm{W}$. This is on the Judd Sheet, which lies 
directly north of Sutherland (Stoker et al., 1993, inside back cover). The Late Pleistocene diamictons and clay-rich suspension deposits were seen to $54 \mathrm{~m}$ (Riding, 2000). The reason for choosing this succession is to test the effectiveness of the $\mathrm{H}_{2} \mathrm{O}_{2}$ preparation procedure on unconsolidated marine clays. The Pleistocene of borehole $99 / 3$ is known to be relatively palynologically rich (Riding, 2000).

Sample 8 was prepared using both $\mathrm{H}_{2} \mathrm{O}_{2}$ and $\mathrm{HCl} / \mathrm{HF}$. Both the preparations yielded abundant and well-preserved indigenous and allochthonous palynomorphs. The abundant reworked palynomorphs are typical of a diamicton-dominated succession. The allochthonous palynomorphs are Carboniferous, Jurassic, Lower Cretaceous, and Paleogene (Eocene to Early Oligocene) and Quaternary dinoflagellate cysts are more common than Quaternary pollen (Riding, 2000). Quaternary dinoflagellate cysts are relatively low in diversity and include Achomosphaera andalousiensis, Bitectatodinium tepikiense, Brigantedinium cariacoense, Brigantedinium simplex, Brigantedinium spp., Impagidinium aculeatum, Lingulodinium machaerophorum, Operculodinium centrocarpum, and Spiniferites spp. The presence of Brigantedinium spp. is indicative of cold, glacial conditions with seasonal or permanent sea-ice (Harland, 1992). Wood fragments are common, and other plant tissues were also observed. There are no differences between the diversities and relative abundances of the $\mathrm{H}_{2} \mathrm{O}_{2}$ and $\mathrm{HCl} / \mathrm{HF}$ preparations, and no damage to the palynomorphs due to oxidative effects of the $\mathrm{H}_{2} \mathrm{O}_{2}$ was observed.

The quantitative analyses of the two preparation methods gave markedly similar results. The $\mathrm{H}_{2} \mathrm{O}_{2}$ and $\mathrm{HCl} / \mathrm{HF}$ preparations yielded 7,700 and 7,600 grains per gram respectively (Table 1). This was the only sample in this study where the $\mathrm{H}_{2} \mathrm{O}_{2}$ preparation produced more palynomorphs than the $\mathrm{HCl} / \mathrm{HF}$ procedure. Non-acid techniques are known to be effective in breaking down soft, unconsolidated clay-rich sediments (Riding and Kyffin-Hughes, 2006; Riding et al., 2006).

\section{CONCLUSIONS}

This demonstration of a reliable palynomorph preparation procedure using hot $\mathrm{H}_{2} \mathrm{O}_{2}$ clearly indicates that the use of mineral acid digestion is not needed in all cases. Five case studies were undertaken, comprising eight samples of Early Carboniferous to Quaternary age from Antarctica, the U.K., and the U.S.A. The samples were prepared quantitatively using $\mathrm{H}_{2} \mathrm{O}_{2}$ and also with $\mathrm{HCl} / \mathrm{HF}$ and/or $\left(\mathrm{NaPO}_{3}\right)_{6}$ in order to provide absolute frequency data that are directly comparable. It is clear from this study that disaggregation using $\mathrm{H}_{2} \mathrm{O}_{2}$, together with density separation, oxidation etc., where necessary, can effectively separate and concentrate palynomorphs from a variety of clay-rich lithologies.

In the Early Carboniferous samples 1 and 2, the $\mathrm{H}_{2} \mathrm{O}_{2}$ method was significantly more effective than the $\left(\mathrm{NaPO}_{3}\right)_{6}$ procedure. However some palynomorphs extracted using $\mathrm{H}_{2} \mathrm{O}_{2}$ appear to have been degraded. Sample 3, which is Late Carboniferous, was prepared effectively using both $\mathrm{H}_{2} \mathrm{O}_{2}$ and $\mathrm{HCl} / \mathrm{HF}$, however the palynomorph concentration is much higher in the $\mathrm{HCl} / \mathrm{HF}$ preparation. However the $\mathrm{H}_{2} \mathrm{O}_{2}$ method produced a residue clear of AOM. Samples 3 and 4 are from a Middle Jurassic paralic deposit and the palynofloras are comparable in terms of both taxonomic content and yield with both the $\mathrm{H}_{2} \mathrm{O}_{2}$ and the $\mathrm{HCl} / \mathrm{HF}$ preparations. Two samples, 6 and 7, are from Danian unconsolidated siliciclastic sediments. These samples represent two different dinoflagellate cyst acmes. The $30 \% \mathrm{H}_{2} \mathrm{O}_{2}$ totally destroyed Palaeoperidinium pyrophorum in sample 6, but did not affect Spinidinium 
sp. in sample 7. The $\mathrm{H}_{2} \mathrm{O}_{2}$ and the $\mathrm{HCl} / \mathrm{HF}$ methods produced similar palynofloras in sample 7, which is a Quaternary clay.

In the majority of the samples studied, the $\mathrm{HCl} / \mathrm{HF}$ technique produced a significantly greater concentration of palynomorphs than either of the non-acid protocols. The $\mathrm{H}_{2} \mathrm{O}_{2}$ method is less effective than $\mathrm{HCl} / \mathrm{HF}$ in disaggregating relatively hard, indurated sedimentary rocks such as sample 3 . However, the $\mathrm{H}_{2} \mathrm{O}_{2}$ procedure appears to be more effective that the $\left(\mathrm{NaPO}_{3}\right)_{6}$ method for indurated claystones. Nevertheless, in most of the Mesozoic and Cenozoic samples, the palynomorph yields of the $\mathrm{H}_{2} \mathrm{O}_{2}$ and $\mathrm{HCl} / \mathrm{HF}$ methods are broadly comparable. Therefore, for both nonacid techniques, the possibility of pre-treating sample material so that it is made significantly softer than in the raw state should be investigated. Potential reagents for this include strong detergents and/or organic solvents.

Hydrogen peroxide can degrade or damage palynomorphs, and evidence of this was noted in samples 1,2 and 6 . In sample 6 , the $30 \% \mathrm{H}_{2} \mathrm{O}_{2}$ was found to completely destroy the dominant species, the dinoflagellate cyst Palaeoperidinium pyrophorum. By contrast, the $\mathrm{HCl} / \mathrm{HF}$ and $\left(\mathrm{NaPO}_{3}\right)_{6}$ procedures both did not adversely affect Palaeoperidinium pyrophorum in this sample. However, the oxidizing effects of $\mathrm{H}_{2} \mathrm{O}_{2}$ can sometimes be useful. For example in sample 3, the $\mathrm{H}_{2} \mathrm{O}_{2}$ method produced a palynomorph assemblage that was cleaner in terms of the levels of extraneous AOM than the residue produced by the acid digestion method. The $\mathrm{H}_{2} \mathrm{O}_{2}$ method has the marked advantage of its capability to macerate the matrix and to oxidize the AOM simultaneously.

Despite the fact that $\mathrm{H}_{2} \mathrm{O}_{2}$ often frequently cannot fully disaggregate indurated lithotypes, if the sample material is abundant in palynomorphs, this method will normally produce abundant and workable associations. It appears to be more effective than $\left(\mathrm{NaPO}_{3}\right)_{6}$ for preparing relatively lithified samples. However, if the sample material is relatively soft and contains palynomorphs susceptible to oxidation, such as sample 6 , the $\left(\mathrm{NaPO}_{3}\right)_{6}$ technique is frequently just as effective. Hence if a non-acid method is required, $\mathrm{H}_{2} \mathrm{O}_{2}$ and $\left(\mathrm{NaPO}_{3}\right)_{6}$ should be used on hard and soft sediments respectively. Further tests should be done on representative material using both $\mathrm{H}_{2} \mathrm{O}_{2}$ and $\left(\mathrm{NaPO}_{3}\right)_{6}$ to determine which non-acid preparation method is most effective. Additionally, more investigations should be undertaken using various concentrations of $\mathrm{H}_{2} \mathrm{O}_{2}$ to further prove its effectiveness in palynological processing.

\section{ACKNOWLEDGEMENTS}

This contribution was funded by the BGS laboratory maintenance and development of capability project managed by Shaun Reeder (BGS, Keyworth). The authors thank Stewart G. Molyneux and Michael H. Stephenson (BGS, Keyworth) for their perceptive reviews of the manuscript. The authors publish with the permission of the Executive Director, British Geological Survey (NERC). Samples 1 and 2 were collected from Springville Hill by Professor Walter L. Manger (University of Arkansas). Samples 6 and 7 were collected on Seymour Island by J. E. Francis, R. W. Raiswell, J. B. Riding, and V. C. Thorn during the Austral summer of 2006 as part of British Antarctic Survey's Antarctic Funding Initiative project number AFI 6/28 project on 'Terminal Cretaceous climate change in Antarctica'. 


\section{References Cited}

\section{ASKIN, R.A.}

1988a Campanian to Paleocene palynological succession of Seymour and adjacent islands, northeastern Antarctic Peninsula. In: Feldmann, R.M., and Woodburne, M.O. (eds.). Geology and paleontology of Seymour Island, Antarctic Peninsula. Geological Society of America Memoir, 169: 131-153.

1988b The palynological record across the Cretaceous/Tertiary transition on Seymour Island, Antarctica. In: Feldmann, R.M., and Woodburne, M.O. (eds.). Geology and paleontology of Seymour Island, Antarctic Peninsula. Geological Society of America Memoir, 169: 155-162.

1990a Campanian to Paleocene spore and pollen assemblages of Seymour Island, Antarctica. Review of Palaeobotany and Palynology, 65: 105-113.

1990b Cryptogam spores from the upper Campanian and Maastrichtian of Seymour Island, Antarctica. Micropaleontology, 36(2): 141-156.

\section{BATTEN, D.J.}

1999 4. Small palynomorphs. In: Jones, T.P., and Rowe, N.P. (eds.). Fossil plants and spores: modern techniques. Geological Society, London, p. 15-19.

BERRIDGE, N.G., PATTISON, J., SAMUEL, M.D.A., BRANDON, A., HOWARD, A.S., PHARAOH, T.C., and RILEY, N.J.

1999 Geology of the Grantham district. Memoir of the British Geological Survey, Sheet 127 (England and Wales). The Stationery Office, London, 133 p.

BROWN, C.A.

1960. Palynological Techniques. Privately published, 1180 Stanford Avenue, Baton Rouge, Louisiana, USA, vi + 188 p.

CLAYTON, G., COQUEL, R., DOUBINGER, J., GUEINN, K.J., LOBOZIAK, S., OWENS, B., and STREEL, $M$.

1977 Carboniferous miospores of western Europe: illustration and zonation. Mededelingen Rijks Geologische Dienst, No. 29, 71 p.

CLAYTON, G., MANGER, W.L., and OWENS, B.

1998 Mississippian (Lower Carboniferous) miospores from the Cuyahoga and Logan formations of northeastern Ohio, USA. Journal of Micropalaeontology, 17: 183-191.

COLEMAN, U., and CLAYTON, G.

1987 Palynostratigraphy and palynofacies of the uppermost Devonian and Lower Mississippian of eastern Kentucky (U.S.A.), and correlation with western Europe. Courier Forschungsinstitut Senckenberg, 98: 75-93.

COLLINSON, M.E. 
1978 Dispersed fern sporangia from the British Tertiary. Annals of Botany, 42: $233-250$.

1980 A new multiple-floated Azolla from the Eocene of Britain with a brief review of the genus. Palaeontology, 23(1): 213-229.

CRAME, J.A., FRANCIS, J.E., CANTRILL, D.J., and PIRRIE, D.

2004 Maastrichtian stratigraphy of Antarctica. Cretaceous Research, 25: $411-423$

DALE, B.

1976 Cyst formation, sedimentation, and preservation: factors affecting dinoflagellate assemblages in Recent sediments from Trondheimsfjord, Norway. Review of Palaeobotany and Palynology, 22: 39-60.

DODSWORTH, P.

1995 A note of caution concerning the application of quantitative palynological data from oxidized preparations. Journal of Micropalaeontology, 14(1): 6.

\section{DOHER, L.I.}

1980 Palynomorph preparation procedures currently used in the paleontology and stratigraphy laboratories, U.S. Geological Survey. United States Geological Survey Circular, No. 830, v +29 p.

ESHET, Y., and HOEK, R.

1996 Palynological processing of organic-rich rocks, or: How many times have you called a palyniferous sample "barren"? Review of Palaeobotany and Palynology, 94: 101-109.

EVITT, W.R., DAMASSA, S.P., and ALBERT, N.R.

1998 A tiger by the tail: the exophragm of the Cretaceous-Paleocene dinoflagellate Palaeoperidinium and its implications. Palynology, 22: 1-55.

FENSOME, R.A., TAYLOR, F.J.R., NORRIS, G., SARJEANT, W.A.S., WHARTON, D.I., and WILLIAMS, G.L.

1993 A classification of living and fossil dinoflagellates. Micropaleontology Special Publication, No. 7, viii +351 p.

FENSOME, R.A., and WILLIAMS, G.L.

2004 The Lentin and Williams index of fossil dinoflagellates 2004 edition. American Association of Stratigraphic Palynologists Foundation, Contributions Series, No. 42: 909 p.

FUNKHOUSER, J.W., and EVITT, W.R.

1959 Preparation techniques for acid-insoluble microfossils.

Micropaleontology, 5(3): 369-375.

GELSTHORPE, D.N. 
2002 Testing of palynological processing techniques: an example using Silurian palynomorphs from Gotland. Journal of Micropalaeontology, 21: 81-86.

GRAY, J.

1965 Techniques in palynology: extraction techniques. In: Kummel, B., and Raup, D. (eds.). Handbook of Paleontological Techniques. W. H. Freeman and Company, San Francisco, p. 530-587.

HARLAND, R.

1989 A dinoflagellate cyst record for the last 0.7 Ma from the Rockall

Plateau, northeast Atlantic Ocean. Journal of the Geological Society, 25: 113-117.

HARLAND, R.

1992 Dinoflagellate cysts of the Quaternary System. In: Powell, A.J. (ed.). A stratigraphic index of dinoflagellate cysts. British Micropalaeontological Society Publications Series. Chapman and Hall, London, 253-272.

HEAD, M.J.

1996 Chapter 30. Modern dinoflagellate cysts and their biological affinities.

In: Jansonius, J., and McGregor, D.C. (eds.). Palynology: principles and applications. American Association of Stratigraphic Palynologists Foundation, Dallas, 3: 11971248.

HOPKINS, J.A., and McCARTHY, F.M.G.

2002 Post-depositional palynomorph degradation in Quaternary shelf sediments: a laboratory experiment studying the effects of progressive oxidation. Palynology, 26:167-184.

HUGHES, N.F., DE JEKHOWSKY, B., and SMITH, A.H.V.

1964 Extraction of spores and other organic microfossils from Paleozoic clastic sediments and coals. Cinquième Congrès International de Stratigraphie et de Géologie Carbonifère, Paris, 9-12 Septembre 1963, Comptes Rendus, 3: 1095-1109.

HYDE, J.E.

1915 Stratigraphy of the Waverley formations of central and southern Ohio. Journal of Geology, 23: 655-682 and 757-779.

\section{INSTITUTE OF GEOLOGICAL SCIENCES}

1975 I.G.S. Boreholes 1974. Report of the Institute of Geological Sciences, No. 75/7, 26 p.

JENKINS, W.A.M.

1967 Ordovician chitinozoa from Shropshire. Palaeontology, 10(3): 436488.

LESCHIK, G.

1956 Sporen aus dem Salzton des Zechsteins von Neuhof (Bei Fulda).

Palaeontographica Abteilung B, 100: 122-142.

MOLYNEUX, S.G., MANGER, W.L., and OWENS, B. 
1984 Preliminary account of Late Devonian palynomorph assemblages from the Bedford Shale and Berea Sandstone Formations of central Ohio, U.S.A. Journal of Micropalaeontology, 3: 41-51.

OWENS, B., and MARSHALL, J. (compilers)

1978 Micropalaeontological biostratigraphy of samples from around the coasts of Scotland. Report of the Institute of Geological Sciences, No. 78/20, 35 p.

PEARSON, T., and SCOTT, A.C.

1999 Chapter 5. Large palynomorphs and debris. In: Jones, T.P., and Rowe, N.P. (eds.). Fossil plants and spores: modern techniques. Geological Society, London, 20-25.

PHIPPS, D., and PLAYFORD, G.

1984 Laboratory techniques for extraction of palynomorphs from sediments. Papers of the Department of Geology, University of Queensland, No. 11, 23 p.

PIRRIE, D., DUANE, A.M., and RIDING, J.B

1992 Jurassic-Tertiary stratigraphy and palynology of the James Ross Basin: review and introduction. Antarctic Science, 4(3): 259-266.

POWELL, A.J.

1992 Dinoflagellate cysts of the Tertiary System. In: Powell, A.J. (ed.). A stratigraphic index of dinoflagellate cysts. Chapman and Hall, London, 155-251.

RIDING, J.B.

1992 A palynological investigation of the BGS Copper Hill Borehole, Lincolnshire (1" sheet 127). British Geological Survey Technical Report, $\mathrm{WH} / 92 / 307 \mathrm{R}, 18 \mathrm{p}$.

2000 A palynological investigation of the Quaternary of BGS Boreholes 99/3 and 99/6 (1999 Rockall Consortium drilling programme). British Geological Survey Technical Report, CR/00/08, 13 p.

RIDING, J.B., and KYFFIN-HUGHES, J.E.

2004 A review of the laboratory preparation of palynomorphs with a description of an effective non-acid technique. Revista Brasileira de Paleontologia, $7(1): 13-44$.

2006 Further testing of a non-acid palynological preparation procedure. Palynology, 30: 69-87.

RIDING, J.B., KEATING, J.M., SNAPE, M.G., NEWHAM, S., and PIRRIE, D. 1992 Preliminary Jurassic and Cretaceous dinoflagellate cyst stratigraphy of the James Ross Island area, Antarctic Peninsula. Newsletters on Stratigraphy, 26: 1939.

RIDING, J.B., WALTON, W., and SHAW, D.

1991 Toarcian to Bathonian (Jurassic) palynology of the Inner Hebrides, north-west Scotland. Palynology, 15: 115-179. 
RIDING, J.B., WILKINSON, I.P., JONES, L.D., and FREEBOROUGH, K. 2006 The occurrence of dinoflagellate cysts in calcareous/siliceous microfossil preparations from the Eocene of southeast England. Journal of Micropalaeontology, 25: 35-36.

SMITH, A.V.H., and BUTTERWORTH, M.A.

1967 Miospores in the coal seams of the Carboniferous of Great Britain. Special Papers in Palaeontology, No. 1, 324 p.

SRIVASTAVA, S.K.

1987 Jurassic spore-pollen assemblages from Normandy (France) and Germany. Geobios, 20(1): 5-79.

STOKER, M.S., HITCHEN, K., and GRAHAM, C.C.

1993 United Kingdom offshore regional report: the geology of the Hebrides and West Shetland shelves, and adjacent deep-water areas. Her Majesty's Stationery Office, London for the British Geological Survey, $149 \mathrm{p}$.

THORN, V.C., FRANCIS, J.E., RIDING, J.B., RAISWELL, R.W., PIRRIE, D., HAYWOOD, A.M., CRAME, J.A., and MARSHALL, J.M.

2007 Terminal Cretaceous climate change and biotic response in Antarctica. In: Cooper, A.K., and Raymond, C.R. (eds.). Online Proceedings of the $10^{\text {th }}$ International Symposium on Antarctic Earth Sciences (ISAES X), August $26^{\text {th }}$ to September $1^{\text {st }} 2007$, Santa Barbara, U.S.A., extended abstract. United States Geological Survey Open-File Report, in press.

TRAVERSE, A.

1988 Paleopalynology. Unwin Hyman, Boston, 600 p.

WILLIAMS, G., PAYNE, S.N.J., DYER, R., EWEN, D.F., PATRICK, N., and WATSON, P.

2005 Non-acid wellsite palynology: widening opportunities. In: Powell, A.J., and Riding, J.B. (eds.). Recent Developments in Applied Biostratigraphy. The Micropalaeontological Society, Special Publication. The Geological Society, London, 219-235.

WINSLOW, M.A.

1962 Plant spores and other microfossils from Upper Devonian and Lower Mississippian rocks of Ohio. United States Geological Survey Professional Paper, No. 364,93 p.

WOOD, G.D., GABRIEL, A.M., and LAWSON, J.C.

1996 Chapter 3. Palynological techniques - processing and microscopy. In: Jansonius, J., and McGregor, D.C. (eds.). Palynology: principles and applications. American Association of Stratigraphic Palynologists Foundation, Dallas, 1: 29-50. 
APPENDIX 1. Description of the new palynological processing technique using hydrogen peroxide $\left(\mathrm{H}_{2} \mathrm{O}_{2}\right)$.

1 The sample is gently crushed to fragments $1000 \mu \mathrm{m} / 1 \mathrm{~mm}$ in maximum diameter; unconsolidated material is gently broken up.

2 The crushed/broken up sample material is placed in a large (ca. $22 \mathrm{~cm}$ diameter) ceramic dish.

3 A few drops of $\mathrm{H}_{2} \mathrm{O}_{2}$ are added to the cold sample material, to test for a violent reaction.

4 The ceramic dish is placed on a hot plate that has been pre-heated to ca. 100 ${ }^{\circ} \mathrm{C}$ in a fume hood.

5 The sample is heated on the hot plate for 1 minute.

6 The sample material is covered with $15 \%$ to $30 \% \mathrm{H}_{2} \mathrm{O}_{2}$, and left to heat for 10 minutes with the hot plate switched on. The concentration of the $\mathrm{H}_{2} \mathrm{O}_{2}$ is dependent upon the level of induration of the rock. The $30 \% \mathrm{H}_{2} \mathrm{O}_{2}$ is only necessary for the hardest of sedimentary rocks and, if the sample material is relatively unidurated, significantly lower concentrations of $\mathrm{H}_{2} \mathrm{O}_{2}$ can be used.

7 The sample residue is then taken off the hot plate and diluted with ca. $250 \mathrm{ml}$ of cold distilled water. The disaggregated sample material then floats, and is carefully decanted into a large (ca. 2-3 liter) beaker. This beaker contains some cold distilled water to further dilute the $\mathrm{H}_{2} \mathrm{O}_{2}$. Care should be taken if the oxidizing reaction is still proceeding.

8 Replace the ceramic dish onto the hot plate and repeat this process as many times as necessary, leaving the sample for longer than 10 minutes if neccessary.

9 Swirl and/or centrifuge or the residue to separate any resistant mineral grains and the organic fraction.

10 Any remaining extraneous AOM can be destroyed using oxidation followed by alkali treatment.

11 The washed residue is then stained if necessary, and concentrated by sieving using an appropriate mesh (normally between 10-15 $\mu \mathrm{m}$ ).

12 The concentrated residue is mounted on microscope slides.

APPENDIX 2. List of samples.

This Appendix lists all the samples with details of sample registration numbers, depths where appropriate, and lithology. The eight samples were registered in the BGS micropaleontological collection and these unique numbers are all prefixed 'MPA' or 'CSA'.

\section{THE PORTSMOUTH MEMBER, CUYAHOGA FORMATION (MISSISSIPPIAN, LOWER CARBONIFEROUS) OF SPRINGVILLE HILL ROAD CUTTING, SOUTH PORTSMOUTH, KENTUCKY, U.S.A.}

This road cutting lies in Kentucky, directly across the Ohio River from Portsmouth, Ohio. The section samples lies on the Portsmouth, Kentucky-Ohio 7.5' quadrangle. It 
is adjacent to U.S. highway 23 at the south end of the U.S. Grant Toll Bridge across the Ohio River at Portsmouth. A prominent bluff is formed by the river, and the road cutting allows access to the river level from the south.

$1 \quad$ MPA $55798 \quad 64.00 \mathrm{~m}$ above the base of the Portsmouth Shale

mudstone

$2 \quad$ MPA $55797 \quad 33.52 \mathrm{~m}$ above the base of the Portsmouth Shale

mudstone

2 THE UPPER CARBONIFEROUS (WESTPHALIAN B) OF BGS OFFSHORE BOREHOLE AT SITE 74/13, EAST OF FIFE NESS, FORTH APPROACHES, SCOTLAND, U.K.

This offshore borehole was drilled $17 \mathrm{~km}$ east of Fife Ness, in the Forth Approaches at $56^{\circ} 18.10^{\prime} \mathrm{N} ; 02^{\circ} 19.30^{\prime} \mathrm{W}$ (Owens and Marshall, 1978, text-figs 1, 3).

$3 \quad$ CSA $1231 \quad 18.07 \mathrm{~m} \quad$ mudstone

3 THE GRANTHAM FORMATION (AALENIAN, MIDDLE JURASSIC) OF THE BGS COPPER HILL BOREHOLE, NEAR ANCASTER, LINCOLNSHIRE, ENGLAND, U.K. (NGR SK 9787 4265)

$\begin{array}{lllll}4 & \text { MPA } 36317 & 5.10-5.20 \mathrm{~m} & \text { Grantham Formation } & \text { mudstone } \\ 5 & \text { MPA } 36320 & 7.00 \mathrm{~m} & \text { Grantham Formation } & \text { mudstone }\end{array}$

\section{THE UPPERMOST LÓPEZ DE BERTODANO FORMATION (DANIAN, LOWER PALEOCENE) OF SEYMOUR ISLAND, ANTARCTIC PENINSULA (MEASURED SECTION D5 229 OF THORN ET AL., 2007)}

Samples 6 and 7 represent acmes of Palaeoperidinium pyrophorum and Spinidinium spp. respectively. The global positioning system (GPS) coordinates are accurate to 5 m. Both samples are silty clays.

$6 \quad$ MPA 56193/D5.1320 $60 \mathrm{~m}$ from base

$64^{\circ} 18^{\prime} 30.2^{\prime \prime} \mathrm{S} ; 056^{\circ} 44^{\prime} 32.8^{\prime \prime} \mathrm{W}$

$7 \quad$ MPA 56194/D5.1309 $50 \mathrm{~m}$ from base

$64^{\circ} 18^{\prime} 29.2^{\prime \prime} \mathrm{S} ; 056^{\circ} 44^{\prime} 38.1^{\prime \prime} \mathrm{W}$

\section{THE QUATERNARY SEDIMENTS OF BGS OFFSHORE BOREHOLE 99/3, FAROES-SHETLAND AREA, OFFSHORE NORTHERN SCOTLAND}

This offshore borehole was drilled in the Judd Sheet, directly north of Sutherland at $60^{\circ} 24.8133^{\prime} \mathrm{N} ; 04^{\circ} 39.0639^{\prime} \mathrm{W}$ (Riding, 2000).
8
MPA $4934034.22 \mathrm{~m}$
Late Pleistocene
clay

APPENDIX 3. Listing of palynomorph species.

All validly published palynomorph taxa, at and below the species level or below mentioned in this contribution are listed here with full author citations. The 
listings are alphabetical within the four major palynomorph groups. A full bibliography on dinoflagellate cyst taxonomy was given by Fensome and Williams (2004).

\section{Dinoflagellate cysts:}

Achomosphaera andalousiensis Jan du Chêne 1977

Bitectatodinium tepikiense Wilson 1973

Brigantedinium cariacoense (Wall 1967) Lentin \& Williams 1973

Brigantedinium simplex Wall 1965 ex Lentin \& Williams 1993

Cassidium fragile (Harris 1965) Drugg 1967

Eisenackia circumtabulata Drugg 1967

Hystrichosphaeridium salpingophorum Deflandre 1935 ex Deflandre 1937

Impagidinium aculeatum (Wall 1967) Lentin \& Williams 1981

Lingulodinium machaerophorum (Deflandre \& Cookson 1955) Wall 1967

Operculodinium centrocarpum (Deflandre \& Cookson 1955) Wall 1967

Palaeoperidinium pyrophorum (Ehrenberg 1843 ex Wetzel 1933) Sarjeant 1967

Senegalinium obscurum (Drugg 1967) Stover \& Evitt 1978

Trithyrodinium evittii Drugg 1967

\section{Miscellaneous microplankton:}

Botryococcus braunii Kützing 1849

\section{Pollen:}

Callialasporites dampieri (Balme 1957) Sukh Dev 1961

Callialasporites microvelatus Schulz 1966

Callialasporites turbatus (Balme 1957) Schulz 1967

Classopollis classoides (Pflug 1953) Pocock \& Jansonius 1961

Florinites junior Potonié \& Kremp 1956

Microcachryidites antarcticus Cookson 1947

Perinopollenites elatoides Couper 1958

Vitreisporites pallidus (Reissinger 1950) Nilsson 1958

\section{Spores:}

Acanthotriletes acritarchus Neville in Neves et al. 1973

Acanthotriletes macrogaleatus Phillips \& Clayton 1980

Acanthotriletes persibus Higgs 1975

Apiculiretusispora fructicosa Higgs 1975

Auroraspora macra Sullivan 1968

Baculatisporites fusticulus Sullivan 1968

Camptotriletes prionotus Higgs 1975

Cibotiumspora juriensis (Balme 1957) Filatoff 1975

Cirratriradites saturni (Ibrahim) Schopf et al., 1944

Colatisporites decorus (Bharadwaj \& Venkatachala) Williams in Neves et al. 1973

Concavissimisporites verrucosus Delcourt \& Sprumont 1955

Convolutispora major (Kedo 1963) Turnau 1978

Coronatispora valdensis (Couper 1958) Dettmann 1963

Crassispora kosankei (Potonié \& Kremp 1955) Bharadwaj 1957

Cristatisporites indignabundus (Loose 1932) Staplin \& Jansonius 1964

Duplexisporites problematicus (Couper 1958) Playford \& Dettmann 1965 
Emphanisporites annulatus McGregor 1961

Endosporites globiformis (Ibrahim 1932) Schopf et al. 1944

Gleicheniidites senonicus Ross 1949

Grumosisporites varioreticulatus (Neves 1958) Smith \& Butterworth 1967

Hymenozonotriletes explanatus (Luber 1941) Kedo 1963

Ischyosporites variegatus (Couper 1958) Schulz 1967

Neoraistrickia logani (Winslow 1962) Coleman \& Clayton 1987

Lycospora pusilla (Ibrahim 1932) Somers 1972

Raistrickia condylosa Higgs 1975

Raistrickia fulva Artüz 1957

Raistrickia saetosa (Loose 1932) Schopf et al. 1944

Raistrickia strumosa Playford 1976

Raistrickia superba (Ibrahim 1933) Schopf et al. 1944

Reinschospora triangularis Kosanke 1950

Retispora lepidophyta (Kedo 1957) Playford 1976

Retispora lepidophyta (Kedo 1957) Playford 1976 var. minor Kedo 1963

Retitriletes austroclavatidites (Cookson 1953) Döring et al. 1963

Retusotriletes incohatus Sullivan 1964

Simozonotriletes intortus (Waltz 1938) Potonié \& Kremp 1954

Spelaeotriletes balteatus (Playford 1963) Higgs 1975

Spelaeotriletes pretiosus (Playford 1964) Neves \& Belt 1970

Spinozonotriletes uncatus Hacquebard 1957

Triquitrites bransonii Wilson \& Hoffmeister 1956

Triquitrites sinani Artüz 1957

Uvaesporites argentiformis (Bolkhovitina 1953) Schulz 1967

Vallatisporites ciliaris (Luber 1938) Sullivan 1964

Vallatisporites pusillites (Kedo 1957) Dolby \& Neves 1970

Vallatisporites vallatus Hacquebard 1957

Vallatisporites verrucosus Hacquebard 1957

Verrucosisporites irregularis Phillips \& Clayton 1980

Verrucosisporites nitidus (Naumova 1953) Playford 1964

Vestispora cancellata (Dybovà \& Jachowicz 1957) Wilson \& Venkatachala 1963

Vestispora costata (Balme 1952) Spode in Smith \& Butterworth 1967 


\begin{tabular}{|c|c|c|c|c|}
\hline $\begin{array}{c}\text { Sample } \\
\text { No. }\end{array}$ & Age & $\begin{array}{c}\text { Palynomorphs per } \\
\text { gram with the 30\% } \\
\mathrm{H}_{2} \mathrm{O}_{2} \text { method }\end{array}$ & $\begin{array}{c}\text { Palynomorphs per gram } \\
\text { with the }\left(\mathrm{NaPO}_{3}\right)_{6} \\
\text { method }\end{array}$ & $\begin{array}{c}\text { Palynomorphs per } \\
\text { gram with the } \\
\text { HF/HCl method }\end{array}$ \\
\hline 1 & $\begin{array}{c}\text { Early } \\
\text { Carboniferous }\end{array}$ & $\mathbf{4 , 0 8 0}$ & 835 & N/A \\
\hline 2 & $\begin{array}{c}\text { Early } \\
\text { Carboniferous }\end{array}$ & $\mathbf{2 , 8 3 0}$ & 390 & N/A \\
\hline & $\begin{array}{c}\text { Late } \\
\text { Carboniferous }\end{array}$ & 2,994 & N/A & $\mathbf{5 4 , 6 0 0}$ \\
\hline 4 & Middle Jurassic & 6,560 & N/A & $\mathbf{7 , 3 7 0}$ \\
\hline 5 & Middle Jurassic & 8,170 & N/A & $\mathbf{8 , 2 5 0}$ \\
\hline 6 & Early Paleogene & 3,575 & 11,700 & $\mathbf{2 2 , 7 0 0}$ \\
\hline 7 & Early Paleogene & 51,810 & N/A & $\mathbf{1 3 0 , 8 5 0}$ \\
\hline 8 & Quaternary & $\mathbf{7 , 7 0 0}$ & N/A & 7,600 \\
\hline
\end{tabular}

Table 1. Table illustrating the numbers of palynomorphs per gram recorded from samples 1 to 8 herein. This material was prepared quantitatively using various combinations of the $30 \% \mathrm{H}_{2} \mathrm{O}_{2},\left(\mathrm{NaPO}_{3}\right)_{6}$, and $\mathrm{HCl} / \mathrm{HF}$ methods. For each sample, the largest palynomorph concentration is in bold type.

Plate captions:

\section{PLATE 1}

A comparison of the hydrogen peroxide $\left(\mathrm{H}_{2} \mathrm{O}_{2}\right)$ and the sodium hexametaphosphate $\left[\left(\mathrm{NaPO}_{3}\right)_{6}\right]$ preparation techniques on sample 1 from the Portsmouth Member of the Cuyahoga Formation, (Mississippian, Lower Carboniferous) of the U.S.A. For scale, which applies to both photomicrographs, the polygonomorph acritarch at the top center of fig. 2 is $127 \mu \mathrm{m}$ in length. Both photomicrographs were taken using plain transmitted light. Note the overall similarity of these two non-acid preparations.

1 the $\mathrm{H}_{2} \mathrm{O}_{2}$ preparation, note the relatively abundant, well-preserved miospores, with occasional acritarchs. The slightly degraded spore at the center-right may have been oxidized by the $\mathrm{H}_{2} \mathrm{O}_{2}$. BGS Slide MPA 55798/2/ $\mathrm{H}_{2} \mathrm{O}_{2} /$ nonquantitative, 'England Finder' coordinate N67/3.

2 the $\left(\mathrm{NaPO}_{3}\right)_{6}$ preparation, note the relatively abundant, well-preserved miospores, with occasional acritarchs. BGS Slide MPA 55798/2/hexa/nonquantitative, 'England Finder' coordinate J60/3.

\section{PLATE 2}

A comparison of the hydrogen peroxide $\left(\mathrm{H}_{2} \mathrm{O}_{2}\right)$ and the mineral acid $(\mathrm{HCl} / \mathrm{HF})$ preparation techniques on sample 3 from the Upper Carboniferous of offshore Scotland. For scale, which applies to both photomicrographs, the saccate pollen grain in the center of fig. 1 is $82 \mu \mathrm{m}$ in length. Both photomicrographs were taken using plain transmitted light. Note the absence and presence of AOM in figs. 1 and 2 respectively. It therefore appears that the $\mathrm{H}_{2} \mathrm{O}_{2}$ simultaneously macerates the rock 
matrix and oxidizes the AOM. The $\mathrm{HCl} / \mathrm{HF}$ preparation (fig. 2) was not separately oxidized.

1 the $\mathrm{H}_{2} \mathrm{O}_{2}$ preparation, note the abundant, well-preserved miospores which are dominated by Lycospora pusilla. The residue is extremely 'clean'; the miospores are free of AOM. BGS Slide CSA $1231 / \mathrm{H}_{2} \mathrm{O}_{2} /$ quantitative, 'England Finder' coordinate L70/4.

2 the $\mathrm{HCl} / \mathrm{HF}$ preparation, again, note the abundant, well-preserved miospores, dominated by Lycospora pusilla. This preparation was not separately oxidized and note the relatively abundant AOM. The AOM partially obscures the miospores, note the prominent specimen of Raistrickia in the center of the field of view which is partially occluded by AOM. BGS Slide CSA 1231/2/HCl-HF/quantitative, 'England Finder'coordinate N57/4.

\section{PLATE 3}

A comparison of the hydrogen peroxide $\left(\mathrm{H}_{2} \mathrm{O}_{2}\right)$ and the mineral acid $(\mathrm{HCl} / \mathrm{HF})$ preparation techniques on sample 5 from the Grantham Formation (Aalenian, Middle Jurassic) of the Copper Hill Borehole, Lincolnshire, U.K. For scale, which applies to both photomicrographs, the specimen of the smooth trilete spore Cyathidites at the top right of fig. 1 is $58 \mu \mathrm{m}$ in diameter. Both photomicrographs were taken using plain transmitted light. Note the relatively abundant miospores in both preparations, and the abundant plant tissue in the $\mathrm{HCl} / \mathrm{HF}$ preparation (fig. 2). It is possible that significant proportions of the lighter plant tissues have been oxidized in the $\mathrm{H}_{2} \mathrm{O}_{2}$ preparation (fig. 1).

1 the $\mathrm{H}_{2} \mathrm{O}_{2}$ preparation, note the relatively abundant miospores, including the saccate pollen Callialasporites, and the clean nature of the residue. BGS slide MPA 36320/3/ $\mathrm{H}_{2} \mathrm{O}_{2}$ /quantiattive, 'England Finder'coordinate P72/2.

2 the $\mathrm{HCl} / \mathrm{HF}$ preparation, note the relatively abundant pollen and spores, including Callialasporites and Cyathidites, and the abundant plant tissue. BGS slide MPA 36320/3/HCl-HF/quantitative, 'England Finder'coordinate Q50.

\section{PLATE 4}

A comparison of the sodium hexametaphosphate $\left[\left(\mathrm{NaPO}_{3}\right)_{6}\right]$ and the mineral acid $(\mathrm{HCl} / \mathrm{HF})$ preparation techniques on sample 6 from the López de Bertodano Formation (Danian, Lower Paleocene) of Seymour Island, Antarctica. For scale, which applies to both photomicrographs, the specimen of the dinoflagellate cyst Palaeoperidinium pyrophorum at the bottom left of fig. 1 is $82 \mu \mathrm{m}$ in length. Both photomicrographs were taken using plain transmitted light. Note the abundant levels of Palaeoperidinium pyrophorum, and the overall similarity of these two preparations. The $\mathrm{H}_{2} \mathrm{O}_{2}$ preparation is not illustrated here; the abundant specimens of Palaeoperidinium pyrophorum have apparently been oxidized by the $30 \% \mathrm{H}_{2} \mathrm{O}_{2}$. 
1 the $\left(\mathrm{NaPO}_{3}\right)_{6}$ preparation, note the relatively abundant, well-preserved specimens of Palaeoperidinium pyrophorum, with occasional other taxa such as Hystrichosphaeridium salpingophorum at the center right. BGS slide MPA 56193/1/( $\left.\mathrm{NaPO}_{3}\right)_{6} /$ non-quantitative, 'England Finder'coordinate P63/1.

2 the $\mathrm{HCl} / \mathrm{HF}$ preparation, note the abundant, specimens of Palaeoperidinium pyrophorum well-preserved miospores, with moderate levels of plant tissue. BGS slide MPA 56193/3/hexa/quantitative, 'England Finder'coordinate M52/3.

\section{PLATE 5}

A comparison of the hydrogen peroxide $\left(\mathrm{H}_{2} \mathrm{O}_{2}\right)$ and the mineral acid $(\mathrm{HCl} / \mathrm{HF})$ preparation techniques on sample 7 from the López de Bertodano Formation (Danian, Lower Paleocene) of Seymour Island, Antarctica. The assemblage is overwhelmingly dominated by the Spinidinium sp., which is a pale, biconical, proximate dinoflagellate cyst. Note the overall similarity of the two preparations. Note that plant tissue is significantly more common in the $\mathrm{HCl} / \mathrm{HF}$ preparation (fig. 2). It is therefore possible that some of the non-woody plant tissues have been oxidized in the $\mathrm{H}_{2} \mathrm{O}_{2}$ preparation (fig. 1). For scale, which applies to both photomicrographs, the abundant representatives of Spinidinium are typically between 40-47 $\mu \mathrm{m}$ long and 27-33 $\mu \mathrm{m}$ wide. Both photomicrographs were taken using phase contrast illumination.

1 the $\mathrm{H}_{2} \mathrm{O}_{2}$ preparation, note the abundant representatives of Spinidinium. BGS slide MPA 56194/3/ $\mathrm{H}_{2} \mathrm{O}_{2}$ /quantitative, 'England Finder' coordinate Q53/1.

2 the $\mathrm{HCl} / \mathrm{HF}$ preparation, again note the abundant Spinidinium spp., a small biconical dinoflagellate cyst. BGS slide MPA 56194/3/HCl-HF/quantitative, 'England Finder' coordinate R52/4.

Proofmarks for Riding/Kyffin-Hughes/Owens:

Global: the author names on the header should not be 'J. B. Riding and J.E. KyffinHughes'; please replace with either 'J. B. Riding et al.' or 'J. B. Riding, J.E. Kyffin-Hughes, and B. Owens'

1 p. 1. Please do not underline my email address.

2 p. 1. Abstract, 9 lines from the bottom. The 'o' in 'López' has an acute accent (ó). Please check this globally; I think that you have got all the others.

3 Check the size of the hyphen on the first line of 'THE PREVIOUSLY DECRIBED.......... Is it too big?

4 p. 3, col. 1, two lines up from base. Please replace the 'to' with 'of'. It should read: '........ on the exposure of the heated.....'

5 p. 3, col. 2, twelve lines up from base. Up-to-date, not Up to date. (insert hyphens).

6 p. 3, col. 2, nine/ten lines up from base. Please do not underline this web address. 
7 p. 4, col. 2, ten lines up from base. U.S.A. and not U.S.A (please insert stop after ' $A$ '.

8 p. 5, col. 2, six lines up from base. well-lithified and not well lithified (insert hyphen).

9 p. 5, col. 2, five lines up from base. It should read: 'In this case, it is....' and not 'In this case, is....' Please insert 'it'.

10 p. 8 Plate 3 , fig 1 explanation. 'quantitative' and not 'quantiattive' please.

11 p. 8, col. 1, three lines down from top. Please insert 'U.K.' after 'England'.

12 p. 10, Plate 5, fig 2 explanation. Two lines from top. '......dominated by Spinidinium sp........' Not '.....dominated by the Spinidinium sp.......' (Delete 'the')

13 p. 10, Plate 5, fig 2 explanation. 'Spinidinium sp.' and not 'Spinidinium spp.' please. (delete a 'p').

14 p. 12, col. 1, line 17. Insert 'U.K.' after 'Scotland'.

15 p. 12, col. 1, line 22. insert 'from', so that it reads: '....clays from offshore....'

16 p. 13, col. 1, line 22. Delete 'often'. It should read: '....H2O2 frequently cannot...' Not '....H2O2 often frequently cannot...' (I.e. delete the superfluous word).

17 p. 17, line 7. 'Spinidinium sp. and not 'Spinidinium spp. (delete 'p').

18 p. 18 , col. 2. Somehow, several names (Kedo)/years ( 8 instances) here are in bold. Can you please make them normal font?

19 Delete the Jim photo on p. 19 (unfortunately!). 